\title{
ORSZÁGSZINTŨ ESG-INDIKÁTOROK SZEREPE A PÉNZÜGYI DÖNTÉSHOZATALBAN
}

Dudás Fanni - Naffa Helena

A környezeti (Environmental), társadalmi (Social) és irányítási (Governance) szempontokat együttesen ESG-indikátoroknak nevezik a pénzügyekben, amelyek az utóbbi időben jelentős figyelmet kaptak a pénzügyi döntéshozatalban. Jelen cikk középpontjában az országszintű ESG-mutatók előrejelző erejének a bemutatása áll a kockázati felárak tekintetében. Elemzésünkben a Világbank országszintű ESG-, valamint a World Governance adatbázisait használtuk, amelyeken neurális hálók módszertant alkalmaztunk az egyes ESG-indikátorok fontosságának méréshez. Két hipotézis keretében vizsgáltuk, hogy az egyes indikátorok fontossága időben és jövedelemcsoportonként állandó-e a kockázati felár becslése esetén. Eredményül azt kaptuk, hogy a kiválasztott ESG-mutatók jelentősége nem állandó az évek során, és a különböző országcsoportok esetében sem. A kapott eredmények alkalmazása több területen is lehetséges: a befektetők könnyebben integrálhatják az ESG-teljesítményeket a pénzügyi döntéshozatalba, valamint a kormányok optimalizálhatják a kockázati költségvetés tervezését, és jobban megalapozott befektetési döntéseket hozhatnak.

JEL-kódok: G11, Q01, Q56

Kulcsszavak: ESG-befektetések, neurális hálók, kockázati prémium, fenntarthatóság

\section{BEVEZETÉS}

2020-ban a koronavírus-járvány kitörése megmutatta, hogy egy regionális probléma hogyan nőhet világszintű válsággá. Annak ellenére, hogy a járvány kitörése csak kevés közvetlen hatást gyakorol az ESG-befektetési szemléletre, ugyanakkor rámutatott arra, ahhoz, hogy egy országról átfogó befektetési értékelést készítsünk, szükségünk van a környezeti (E), a szociális (S) és a kormányzás (G) ténye-

1 Dudás Fanni PhD-hallgató, Befektetések és Vállalati Pénzügy Tanszék, Budapesti Corvinus Egyetem. E-mail: fanni.dudas@uni-corvinus.hu.

Naffa Helena PhD, egyetemi adjunktus, Befektetések és Vállalati Pénzügy Tanszék, Budapesti Corvinus Egyetem. E-mail: helena.naffa@uni-corvinus.hu. 
zők mélyreható elemzésére. Ezen indikátorok segítségével részletes képet kaphatunk egy ország sebezhetőségéről és kitettségéről (RobecoSAM, 2020b).

Az ESG-indikátorokkal, valamint a pénzügyi döntéshozatalban betöltött szerepükkel már jelentős mennyiségű szakirodalom foglalkozott, ugyanakkor jellemzően vállalati szinten vizsgálták a cégek társadalmi felelősségvállalása és a gazdasági teljesítményük közötti kapcsolatokat (Friede és mtsai., 2015). Ugyanakkor az ESG-indikátorok országszinten is értelmezhetők, mint például a hitelminősítések, amelyek egy átfogó keretrendszert alkotnak az országok teljesítményének elemzéséhez az ESG-indikátorok mentén és egyre nagyobb szerepet kapnak a pénzügyi döntéshozatalban. Az ESG-tényezők értékelésekor egy átfogó képet kapunk az adott országról fenntarthatóság szempontjából, kitérve a gyengeségekre és erősségekre (RobecoSAM, 202ob). Ezen jellemzők azonban nem részei a hagyományos szuverén kockázati besorolásnak, de együtt alkalmazva az ESGelemzésekkel, hatékony eszközök lehetnek az államkötvények kockázatelemzésének javítására, valamint hogy megértsük az eredendő hosszú távú kockázatokat mind értékalapú, mind gazdasági szempontból (Comble és mtsai., 2019), ellentétben az osztalékalapú gondolkodással (Kerti-Keresztúri, 2017).

Ebben a cikkben az országszintű ESG-mutatók előrejelző erejének feltárására összpontosítunk. A releváns szakirodalom alapján kiválasztjuk a releváns ESGmutatókat, majd neurális hálók módszertannal elemezzük az egyes prediktorok fontosságát a kockázati felár előrejelzése esetében. Két hipotézisen keresztül teszteltük, hogy az egyes mutatók fontossága az évek során állandó marad-e, illetve az egyes mutatók fontossága állandó marad-e különböző jövedelmi csoportok esetén egy adott évben.

Ezzel a kutatással három módon járulunk hozzá a meglévő szakirodalomhoz. Elsősorban azzal, hogy az elemzésünkben a RobecoSAM ESG-minősítési módszertanát alkalmaztuk, és a következő ESG-mutatókat választottuk ki a vizsgálathoz: a környezeti kockázat, a környezeti állapot, az öregedés, a társadalmi nyugtalanság, a korrupció, az intézményrendszer és a politikai kockázat (RobecoSAM, 2020a). Továbbá, az alkalmazott módszertannal nem az egyes determinánsok előrejelző erejét, hanem az egyes tényezők fontosságát mérjük a különböző időhorizontokon és jövedelemi szinteken. Végül pedig a neurális hálók módszertant alkalmaztuk az egyes mutatók fontosságának elemzésére, amire eddig kevés példa volt a szakirodalomban.

A cikk további része az alábbiak szerint tagolódik. Először a releváns szakirodalmat és a releváns kutatási hátteret tárgyaljuk, majd a javasolt elméleti keretet mutatjuk be. Ezután részletesen áttekintjük az alkalmazott empirikus vizsgálatokat, majd az egyes hipotézisvizsgálatok részleteit és eredményeit mutatjuk be. A cikk ezeknek az eredményeknek az összegzésével, lehetséges alkalmazásukkal, valamint a jövőbeli kutatási irányok bemutatásával és korlátaival zárul. 


\section{ELMÉLETI HÁTTÉR}

Az ESG-indikátorok szerepét a pénzügyi döntéshozatalban számos cikk is vizsgálja a szakirodalomban, ugyanakkor elsősorban vállalati szinten. Jelen cikk az országszintű ESG-indikátorok szerepét vizsgálja, ennek megfelelően szeretnénk kiemelni a fontosabb forrásokat, külön kitérve a cikk újdonságát adó módszertanra, a neurális hálókra.

Hübel (2020) tanulmányában elemezte az országok környezeti, társadalmi és kormányzati (ESG) teljesítményének szerepét a szuverén CDS-piacokon. 60 országot vizsgált 2007 és 2017 között, és megállapította, hogy a kiváló ESG-teljesítményű országok nemcsak alacsonyabb CDS-felárat értek el, hanem laposabb CDSimplicit hitelgörbéket is mutattak. Lineáris regressziós és kétváltozós statisztikákat alkalmazott tanulmányában, valamint RobecoSAM ESG-minősítéseket is használt az ország fenntarthatóságának mérésére.

De Franco és mtsai. (2020) gépi tanulási algoritmust alkalmaztak cikkükben, amely azonosítja az ESG-profilok és a pénzügyi teljesítmények mintáit a nagy befektetési univerzumban lévő vállalatok esetében. Azáltal, hogy az ESGfunkciókat nemlineáris módon összekapcsolják a pénzügyi teljesítményekkel, a gépi tanulási algoritmusukon alapuló stratégiájuk hatékony részvényválasztó eszköznek bizonyul, amely felülmúlja azokat a klasszikus stratégiákat, amelyek az ESG-besorolásuk szerint szűrik a részvényeket. De Lucia és mtsai. (2020) azt tanulmányozták, hogy az ESG-mutatók és más gazdasági mutatók alapján előre jelezhetők-e a vállalatok főbb pénzügyi mutatói, mint például a vizsgált vállalkozások sajáttőke-arányos nyeresége (ROE) vagy az eszközarányos nyeresége (ROA), valamint hogy az ESG-kezdeményezések befolyásolják-e az állami vállalkozások pénzügyi teljesítményét. De Lucia és mtsai. szintén gépi tanulási technikákat alkalmaztak a cikkükben. Elemzésük során megállapították, hogy a gépi tanulási módszerek pontosan megjósolják a ROA-t és a ROE-t, és logisztikai regressziós modellen keresztül jelzik az ESG-gyakorlatok és a pénzügyi mutatók közötti pozitív kapcsolat létezését az állami vállalkozások esetében.

Crifo és mtsai. (2017) az országszintű ESG-mutatók és az államkötvényhozamok közötti kapcsolatot vizsgálták ökonometriai modellekkel. Kutatási kérdésük arra irányult, hogy az országok környezeti, társadalmi és kormányzási (ESG) tényezőinek jól teljesítése számít-e az államkötvénypiac szempontjából. A kutatók 23 OECD-országot vizsgáltak meg 2007 és 2012 között panelregressziós modell segítségével. Az elemzésük eredményeként azt kapták, hogy a jó ESG-minősítések és teljesítmények jelentősen csökkentik az államkötvényfelárakat, azaz megéri jó ESG-minősítéssel rendelkezniük az országoknak.

Capelle-Blancard és mtsai. (2016, 2019) szintén az országok ESG-teljesítménye és az államkötvényfelárak közötti kapcsolatokat vizsgálták. Megfigyelték, hogy 
a jó ESG-teljesítményű országokban általában kisebb a nemteljesítési kockázat, ezáltal alacsonyabb a kötvényfelár. Azt is megállapították, hogy a gazdasági hatás hosszú távon erősebb, ami arra utal, hogy az ESG-teljesítmény hosszú távon fejti ki hatását. Megvizsgálták az egyes ESG-dimenziók pénzügyi hatását külön-külön is: az eredmények azt sugallják, hogy a környezeti dimenziónak nincs jelentős pénzügyi hatása, míg a kormányzati indikátoroknak volt a legmeghatározóbb súlya, amely meghaladta a társadalmi mutatókat is. Munkájuk során panelmodellt, valamint fökomponens-elemzést használtak az ESG-index létrehozásához. Tarmuji és mtsai. (2016) az országszintű ESG-mutatók és az országok gazdasági teljesítménye közötti kapcsolatot elemezték. Kutatásuk során két ország, Malajzia és Szingapúr nem pénzügyi adatait vizsgálták 2010 és 2014 között. Munkájuk eredményei azt mutatták, hogy a társadalmi és kormányzási gyakorlatok jelentősen befolyásolják a gazdasági teljesítményt. Vizsgálatukban leíró statisztikát, korrelációs elemzést és lineáris regressziót alkalmaztak az adatok elemzéséhez.

Korábban más szerzők is vizsgálták az országkockázati felárak és a különböző nem pénzügyi mutatók közötti kapcsolatot. Ebner (2009) jelentős különbségeket fedezett fel a közép- és kelet-európai piacon az államkötvényfelárakban a válság sújtotta, valamint a nem válságos időszakokban. Az észlelt eltérést a politikai instabilitással és bizonytalansággal magyarázta. Eichler (2013) a feltörekvő országok mintájára készítette el a megfigyeléseit, és ennek az alapján megállapította, hogy a vizsgált országokban az államkötvényhozam-felárakat befolyásolja az adott ország politikai rendszere. Eredményül azt kapta, hogy azon országok, ahol parlamentáris rendszer müködik, nagyobb kockázati felárral szembesülnek, mint ahol elnöki rendszerben kormányoznak. Kiemelte azonban azt is, hogy a kormányzás minősége hozzájárul a kamatfelárak csökkentéséhez. Connolly (2007) az államkötvényfelárak és a korrupció közötti összefüggéseket vizsgálta munkájában. Megállapította, hogy a Transparency International korrupcióindexe rontotta az országok hitelbesorolását, és úgy vélte, hogy a kormányzás átláthatóbba és kevésbé korrupttá tételére tett erőfeszítések javítanák a hitelminősítéseken, azaz csökkentenék az államadósság költségeit. Margaretic és Pouget (2014) munkájukban a környezeti teljesítmény indexet (EPI) vizsgálták, és megállapították, hogy az EPI-mutató hozzájárul a kockázati felárak várható értékének és volatilitásának pontosabb megértéséhez a feltörekvő piacokon.

Kutatásunkban az ESG-minősítések számítási módszere is fontos szerepet játszik. Az ESG-minősítő intézetek szakértelmükkel kulcsfontosságú referenciaponttá nőtték ki magukat egy vállalat vagy egy ország ESG-értékelése esetén. Escrig-Olmedo és mtsai. (2019) összehasonlító tanulmányt készítettek az ESGminősítések különböző módszertanairól. Tanulmányukban azt találták, hogy az ESG-minősítő intézetek a környezeti, társadalmi és irányítási kritériumok elemzésére összpontosítanak, míg a gazdasági dimenziót kevésbé tanulmányozzák. Sőt 
megfigyelték, hogy az ESG-minősítő intézetek nem integrálják teljes mértékben a fenntarthatósági elveket a vállalati fenntarthatósági teljes értékelési folyamatába. Alapos elemzést végeztek arról, hogy a környezeti kritériumok hogyan változtak 2008 és 2018 között az ESG-minősítö ügynökségeknél a vállalatok esetében. 2008ban a legelterjedtebb elemzési kritériumok a környezeti politika (100\%), a károsanyag-kibocsátás $(62,5 \%)$ és az éghajlatváltozás (50\%), míg 2018-ban a fö elemzett kritérium a környezeti politika (87,5\%), a vízgazdálkodás (87,5\%), valamint a biológiai sokféleség védelme (87,5\%) voltak. Az eredmények alapján 2018-ban nagyobb érdeklődést mutattak a vállalatok a környezeti problémák iránt, mint 2008-ban. A társadalmi mutatók esetében 2008-ban az ESG-minősítő intézetek a humántőke-fejlesztés értékelési folyamatát is elemezték: humántőke fejlesztése és képzés (100\%), emberi jogok (87,5\%) és a közösségi kapcsolatok $(87,5 \%)$ kerültek a legfontosabb szempontok közé, 2018-ra ezek beépültek minden ESG-minősítő intézet értékelési folyamatába. Az irányítási pillér kapcsán megállapították, hogy a vállalatirányítási funkciók és bizottságok (100\%), az igazgatóság felépítése (75\%) és a javadalmazási/kompenzációs politika (62,5\%) voltak a legfontosabb kritériumok. Ezeket a kritériumokat, amelyeket a vállalatirányítási kódexek általában tartalmaznak, 2018-ban is fontosnak tartották. A korrupció és a megvesztegetés megelözésének növekedésével kapcsolatos, valamint az átláthatósági kérdések azonban jelentős különbséget mutatnak 2008 és 2018 között, mivel ezek 87,5\%-kal a második legfontosabb elemzési szemponttá léptek elő (Escrig-Olmedo és mtsai., 2019:10-12.).

\section{MODELL ÉS HIPOTÉZISEK}

Kutatásunk során az országszintü ESG-indikátorokat elemezzük neurális hálókkal, amely egy gépi tanulási módszertan. A gépi tanulási módszerek használata az ESG-mutatók és a kockázati prémium elemzésére nem ritka a szakirodalomban. Hübel (2020), De Franco és mtsai. (2020), valamint Capelle-Blancard és mtsai. (2016; 2019) adnak keretet a kutatásunknak.

Hübel (2020) munkája alapján RobecoSAM által használt ESG-metodológiát használtuk, amelynek értelmében 50\%-ban kormányzati, 30\%-ban szociális, valamint 20\%-ban környezeti indikátorokat mint magyarázó változókat alkalmaztuk az elemzésünkben. De Franco és mtsai. (2020) cikke alapján én is a gépi tanulási módszereket választottuk alkalmazott módszertanként a kutatásban. CapelleBlancard és mtsai. (2016; 2019) cikke alapján pedig a független változó a hitelezési kockázati prémium a modellben.

Ezen keretek között két hipotézist vizsgáltunk: 
- H1: Az egyes ESG-mutatók fontossága a hitelkockázati prémium meghatározásában az évek során állandó.

- H2: Az egyes ESG-mutatók fontossága a hitelkockázati prémium meghatározásában a különböző jövedelmi csoportokban állandó.

\section{MÓDSZERTAN ÉS ADATOK}

Kutatásunk során a Világbank által közzétett, globális ESG-mutatók adatbázisát használtuk fel (World Bank, 2020a). A Világbank eredeti adatbázisa 68 ESGmutatót tartalmaz 239 országra és országcsoportra. Az elemzéshez hét változót választottunk ki az ESG-mutatók közül a RobecoSAM (2020a) mutatói és az országos szintü ESG-tényezőkre vonatkozó, releváns szakirodalom alapján (CapelleBlancard és mtsai., 2016; 2019). A RobecoSAM egy ország ESG-pontszámát 40 különböző mutató alapján számítja ki, amelyek a környezeti, társadalmi és kormányzási tényezőket mérik.

A tényezőket a három ESG dimenzióban az alábbiak szerint súlyozzák: 20\% a környezeti, 30\% a társadalmi és 50\% az irányítási tényezőkre (RobecoSAM, 2020a).

Kutatásunkba a következő változókat vettük be:

Környezeti tényezők - $20 \%$

- Környezeti kockázat: erdőterület (a földterület százaléka)

- Környezeti állapot: PM2.5 légszennyezés, átlagos éves kitettség (mikrogramm/ köbméter)

\section{Szociális tényezők - 30\%}

- Öregedés: várható életkor születéskor, összesen (év), 65 éves és idősebb népesség aránya (a teljes népesség százaléka)

- Szociális nyugtalanság: munkanélküliség (\%)

Irányítási tényezők - 50\%

- Korrupció: a korrupció mértékének becslése

- Intézmények: a kormány hatékonysága: becslés

- Jogállamiság: becslés

- Politikai kockázat: politikai stabilitás és erőszak/terrorizmus hiánya: becslés

- Sajtószabadság és elszámoltathatóság: becslés

Kutatásunk 127 országra és két évre, a 2016-os és 2010-es évekre terjed ki. A hipotézis teszteléséhez további adatokat használtunk a Világbank adatbázisából, kockázati prémiumként a hitelezési kockázati prémiumot (\%) alkalmaztuk (World Bank, 202ob). 
Az alkalmazott módszertan neurális hálózatok módszer volt az SPSSS-ben, pontosan a Multilayer Perceptron módszer, amelynek célja az volt, hogy feltárja az egyes változók fontosságát a kockázati prémium kapcsán. A Multilayer Perceptron (MLP) eljárás prediktív modellt állít elő egy vagy több függő (cél-) változó számára a prediktor változók értéke alapján (IBM, 2020). Ez egyfajta neurális hálózat, legalább három csomópontból áll: egy bemeneti, egy rejtett és egy kimeneti rétegből.

A neurális hálók módszere a gépi tanulás egyik elterjedt módszertana. A gépi tanulási módszerek használata a változók meghatározó erejének elemzésére napjainkban az egyik leggyakrabban használt technika a különböző pénzügyi jelenségek elemzésekor. A gépi tanulásnak (angolul Machine Learning - ML) számos definíciója van a szakirodalomban. Gu és mtsai. (2020) szerint a gépi tanulás módszereinek meghatározása a következő: a statisztikai előrejelzéshez használt nagy dimenziós modellek sokszínű gyüjteménye, kombinálva az úgynevezett „törvényesítési” módszerekkel a modellválasztáshoz és a túlillesztés mérsékléséhez, valamint a hatékony algoritmusok nagyszámú potenciális modellspecifikációjának összessége. Az ML-módszerek a következő esetekben lehetnek optimálisabbak, mint a többi hagyományos módszertan: először is a gépi tanulás módszerei rugalmasak, illetve ezek a módszerek a mintán kívüli is stabil eredményeket hoznak. Az ML-módszerek optimálisak lehetnek az előrejelzési problémákra a prediktorok közötti redundáns variációk sürítésével. Végül a gépi tanulási módszerek a nemlineáris kapcsolatokat és interakciókat is tudják kezelni.

\section{EREDMÉNYEK}

Jelen kutatásban a különböző ESG-indikátorok fontosságát elemeztük a hitelezési kockázati prémium meghatározásával kapcsolatban. Két hipotézisen keresztül vizsgáltuk $\left(H_{1}, H_{2}\right)$, hogy ezen tényezők állandóak-e időben és különböző jövedelemcsoportokra vetítve.

\subsection{Hipotézis 1}

Először $H_{1}$ hipotézist teszteltük Multilayer Perceptron módszerrel. A 2010-es és 2016-os évek adatait használtuk fel és az eredmények a következők (1. ábra és 2. ábra): 


\section{1. ábra}

\section{Az egyes ESG-indikátorok normalizált fontossága 2016-ban (\%)}

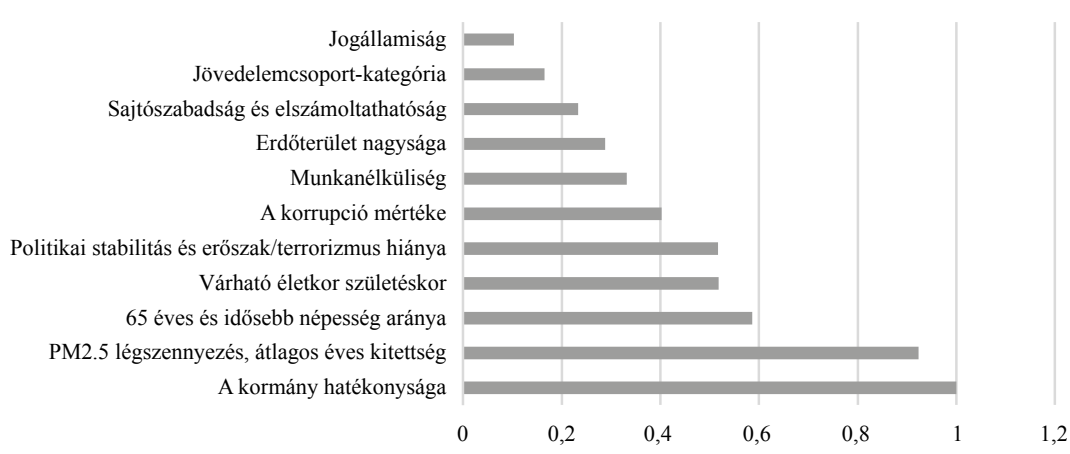

Forrás: World Bank (2020a, 2020b)

A kapott eredmények alapján megállapítjuk, hogy a hitelezési kockázati prémium meghatározása szempontjából a legfontosabb mutató a kormányzás hatékonysága és a légszennyezés, majd a 65 év felettiek aránya. Az eredmények tehát azt mutatják, hogy a nagyobb arányban reprezentált irányítási tényezők nem bírnak nagyobb jelentőséggel a hitelezési kockázati prémium előrejelzése szempontjából, mint a társadalmi vagy környezeti tényezők. A legfontosabb mutató mellett a legkevésbé fontos tényezők a jogállamiság és a sajtószabadság/elszámoltathatóság voltak, amelyek szintén az irányítás (governance) csoportba tartoznak.

\section{2. ábra}

\section{Az egyes ESG-indikátorok normalizált fontossága 2010-ben (\%)}

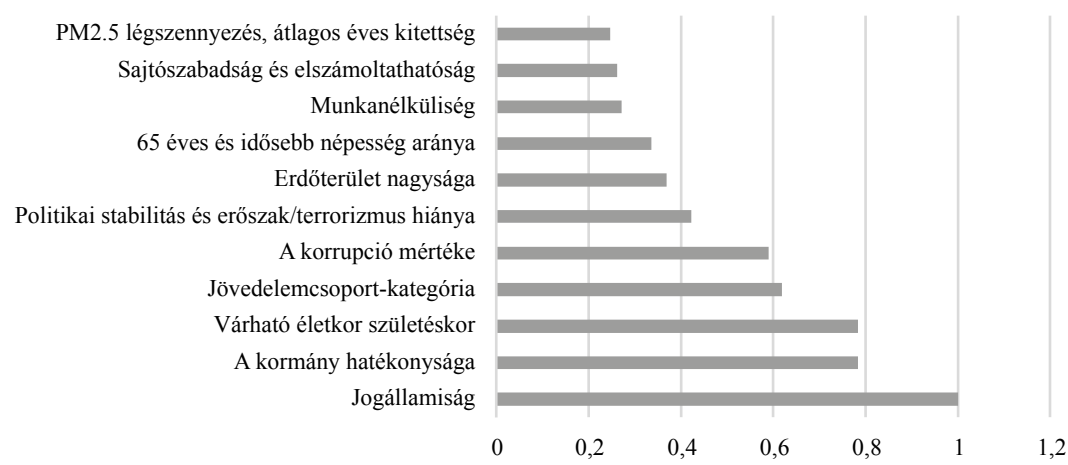

Forrás: World Bank(2020a, 202ob, 2020c) 
2010 esetében láthatjuk, hogy a kormányzás hatékonysága és a jogállamiság voltak a legfontosabb tényezők a hitelezési kockázati prémium meghatározásában, míg a sajtószabadság/elszámoltathatóság és a légszennyezés kevésbé fontos.

Összefoglalva azt láthatjuk, hogy az ESG-mutatók jelentősége a hitelezési kockázati prémium meghatározásában nem állandó, mivel az egyes években másmás tényezők voltak fontosak, ezért összevetve a 2010. és 2016. évekre kapott eredményeket, a H1-et elutasítottuk.

\subsection{Hipotézis 2}

A második hipotézis $\left(\mathrm{H}_{2}\right)$ vizsgálatakor megvizsgáltuk a négy különböző jövedelemcsoport-kategóriát a Világbank szerint a 2016-os évre. A jövedelemcsoportkategóriák az egy főre eső éves GNI-től függnek, ennek az alapján négy csoportot különböztet meg a Világbank: az alacsony jövedelmü gazdaságokat úgy definiálják, hogy az egy főre jutó GNI a Világbank számítási módszerével számolva 1035 amerikai dollár vagy az alatti; a közepesen alacsony jövedelmü gazdaságok azok, amelyekben az egy före jutó GNI értéke 1036 és 4045 amerikai dollár között van; a közepesen magas jövedelmű gazdaságok azok, amelyekben az egy före jutó GNI értéke 4046 és 12535 amerikai dollár közötti; a magas jövedelmü gazdaságok azok, amelyekben az egy főre jutó GNI értéke legalább 12536 amerikai dollár (World Bank, 2020c).

Először a magas jövedelmű országokat vizsgáltuk meg, a kapott eredményeket a 3. ábra személteti.

\section{3. ábra}

Az egyes ESG-indikátorok normalizált fontossága 2016-ban a magas jövedelmü országokban

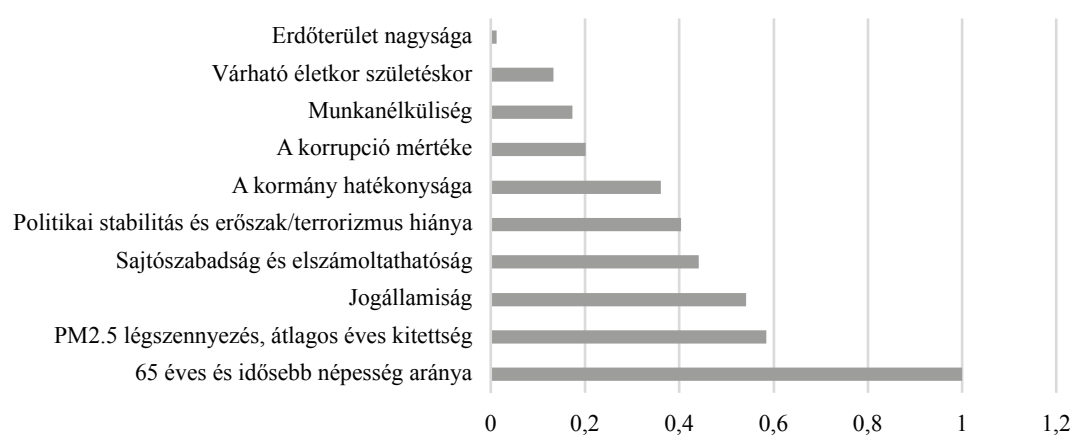

Forrás: World Bank (2020a, 2020b, 2020c) 
A grafikonon láthatjuk, hogy a legfontosabb mutatók a 65 év felettiek aránya és a levegőszennyezés mértéke, míg kevésbé fontosak az erdőterület nagysága és a várható élettartam voltak. A kapott eredmény némileg összhangban van az 1. ábra világszintű eredményeivel, a második helyen a levegőszennyezés szerepel mindkét esetben, illetve a 65 év felettiek aránya első, illetve harmadik helyeken.

A következő, 4. ábra a közepesen magas jövedelmű országok eredményeit mutatja.

4. ábra

Az egyes ESG-indikátorok normalizált fontossága 2016-ban a közepesen magas jövedelmü országokban

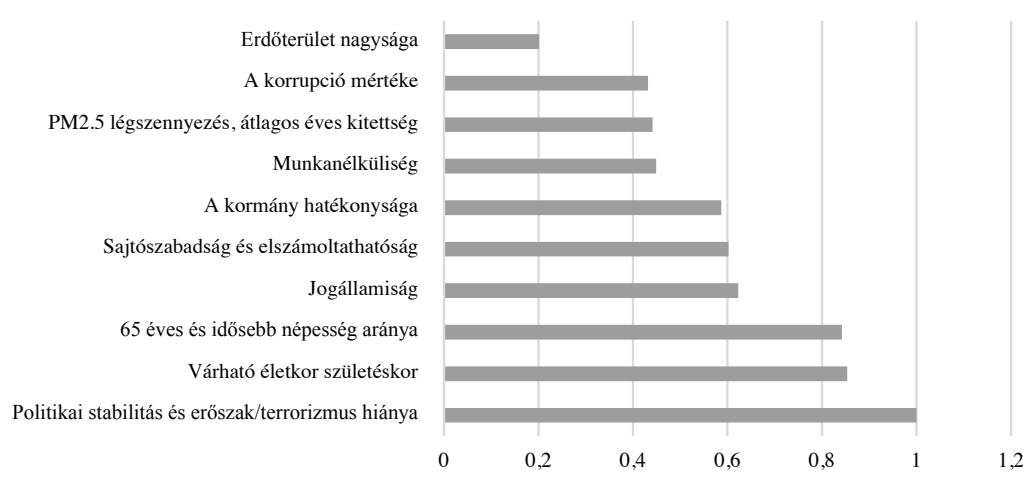

Forrás: World Bank (202Oa, 2020b, 2020c)

A 4. ábra azt mutatja, hogy a közepesen magas jövedelmű országok esetében a hitelezési kockázati prémium meghatározásában a legfontosabb tényező a politikai stabilitás, amely a magas jövedelmű csoportok és a világméretű eredmények esetében a közepesen fontos mutatók közé tartozott. A várható élettartam a második legfontosabb, illetve ezt követi a 65 év feletti lakosság aránya, ami azt jelenti, hogy ebben a jövedelmi csoportban a társadalmi tényezőknek fontosabb meghatározó erejük van a hitelkockázati prémium definiálásban, mint más jövedelmi csoportoknál. 
5. ábra

Az egyes ESG-indikátorok normalizált fontossága 2016-ban a közepesen alacsony jövedelmü országokban

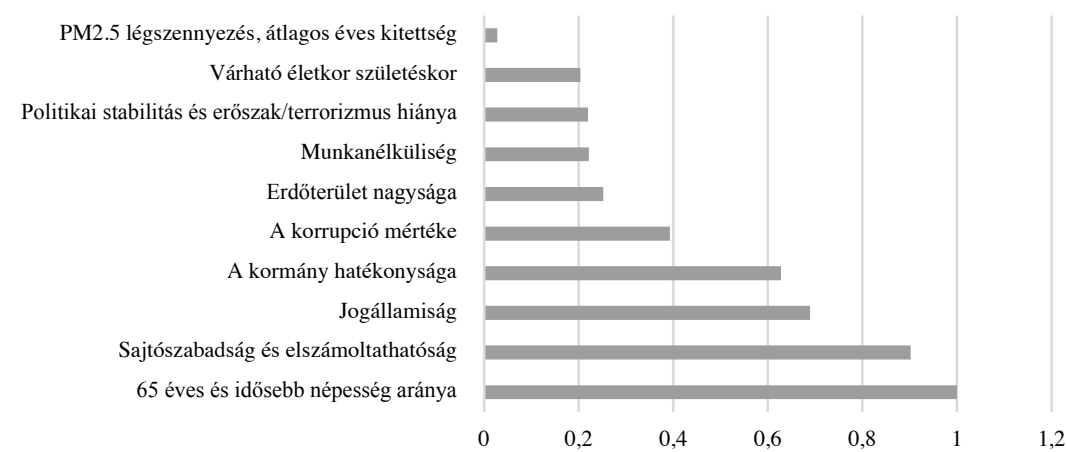

Forrás: World Bank (2020a, 2020b, 2020c)

Az 5. ábra a közepesen alacsony jövedelmü országok eredményeit mutatja be. Ebben az esetben a 65 év feletti népesség aránya a legfontosabb, míg a levegöszennyezés és a várható élettartam a kevésbé fontos tényezők. Érdekes tény, hogy az irányítási, kormányzattal összefüggő mutatók ebben az esetben mind a lista elején találhatók.

\section{6. ábra}

\section{Az egyes ESG-indikátorok normalizált fontossága 2016-ban az alacsony jövedelmü országokban}

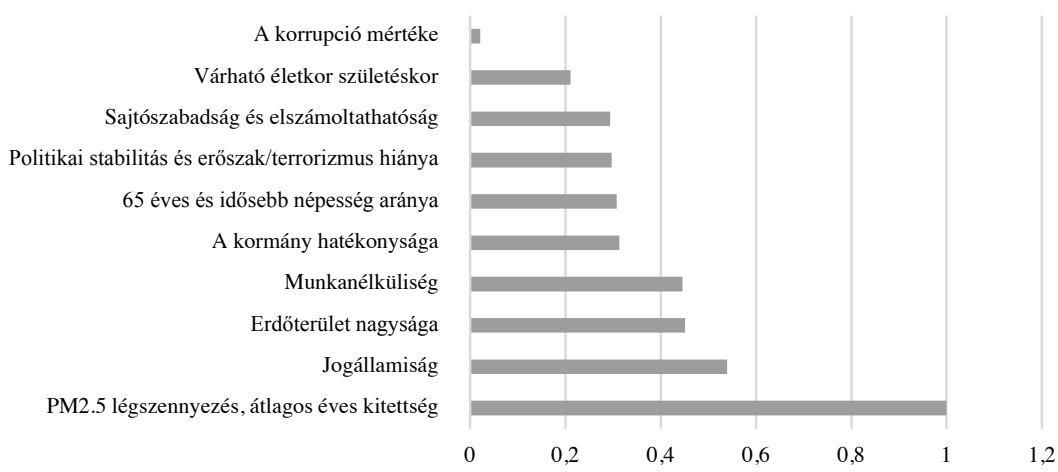

Forrás: World Bank (2020a, 2020b, 2020c) 
Az alacsony jövedelmű csoport esetében a légszennyezés a legfontosabb meghatározó tényező és a jogállamiság a második, míg a kormányzási tényezők ebben a jövedelmi csoportban a kevésbé vagy közepesen fontosak a hitelkockázati prémium meghatározásához.

Összegezve az eredményeket a $\mathrm{H}_{2}$ esetében, elvetettük azt a hipotézist, amely szerint az ESG-mutatók jelentősége a hitelezési kockázati prémium meghatározásában a jövedelmi csoportok vonatkozásában ugyanaz marad, mivel különböző mintázatokat kaptunk eredményül az egyes jövedelemcsoportokban.

\section{6. ÉRTEKEZÉS}

Az első hipotézis eredményeit vizsgálva, a kormányzás hatékonysága mind 2010ben, mind 2016-ban fontos tényező volt, míg a környezeti tényezők 2016-ban fontosabbak voltak, mint 2010-ben. Az eredmények alapján úgy tünik, hogy a kormányzás és a társadalmi tényezők nagyobb jelentőséget kaptak 2010-ben, mint 2016-ban.

Ezek az eredmények arra engednek következtetni, hogy a kormányzás és a társadalommal kapcsolatos mutatók mellett fontos, hogy a környezeti problémákra is figyeljünk, és ezen tényezők együtt egyre fontosabb szerepet kapjanak az országok hitelezési kockázati prémiumának értékelésében. A kapott eredmények alapján részben értünk egyet RobecoSAM ESG-besorolási számításával, mivel a modelljükben 50\%-os súlyt adnak a kormányzással kapcsolatos mutatókra, 30\%ot a társadalmi indikátoroknak, és mindössze $20 \%$-ot a környezeti mutatóknak.

A második hipotézis tesztelésekor az alábbi eredmények születettek a különböző jövedelemcsoportoknál:

1. táblázat

A H2 vizsgálatának eredménye

\begin{tabular}{|c|c|c|}
\hline $\begin{array}{l}\text { Jövedelemcsoport- } \\
\text { kategória }\end{array}$ & $\begin{array}{l}\text { Legfontosabb } \\
\text { mutatók }\end{array}$ & $\begin{array}{l}\text { Legkevésbé fontos } \\
\text { mutatók }\end{array}$ \\
\hline Magas & $\begin{array}{c}65 \text { év feletti népesség aránya } \\
\text { Levegőszennyezés }\end{array}$ & $\begin{array}{l}\text { Várható élettartam } \\
\text { Erdőterület nagysága }\end{array}$ \\
\hline $\begin{array}{l}\text { Közepesen } \\
\text { magas }\end{array}$ & $\begin{array}{l}\text { Politikai stabilitás } \\
\text { Várható élettartam }\end{array}$ & $\begin{array}{c}\text { Erdőterület nagysága } \\
\text { Korrupció }\end{array}$ \\
\hline $\begin{array}{l}\text { Közepesen } \\
\text { alacsony }\end{array}$ & $\begin{array}{l}65 \text { év feletti népesség aránya } \\
\text { Sajtószabadság/elszámoltathatóság }\end{array}$ & $\begin{array}{l}\text { Várható élettartam } \\
\text { Levegőszennyezés }\end{array}$ \\
\hline Alacsony & $\begin{array}{l}\text { Levegőszennyezés } \\
\text { Jogállamiság }\end{array}$ & $\begin{array}{c}\text { Várható élettartam } \\
\text { Korrupció }\end{array}$ \\
\hline
\end{tabular}

Forrás: saját szerkesztés 
Ezek az eredmények szintén megerősítik az első hipotézis során levont következtetéseket, azaz a társadalmi és az irányítási mutatók mellett a környezeti indikátoroknak a jelentőségét nem becsülhetjük alá. Ez az eredmény részben ellentmond Capelle-Blancard és mtsai. (2016; 2019), valamint Tarmuji és mtsai. (2016) elemzéseinek, amelyek szerint a környezeti dimenziónak nincs pénzügyi hatása, míg a kormányzás súlya meghaladja a társadalmi tényezőkét.

Az eredmények azonban megegyeznek Escrig-Olmedo és mtsai. (2019) eredményeivel, akik megállapították, hogy 2018-ban nagyobb az érdeklődés a környezeti problémák iránt, mint 2008-ban, erre itt is találtunk bizonyítékot.

Kutatásunk eredményeinek számos gyakorlati haszna lehet. Ennek alapján a befektetők átláthatóbban integrálhatják az ESG-teljesítményeket a pénzügyi döntéshozatalba. A kormányok optimalizálhatják a kockázati költségvetés tervezését, és jobban megalapozott befektetési döntéseket hozhatnak. Ezen túl a koronavírus-járvány felhívta a figyelmet arra: átfogó ESG-elemzésre van szükség ahhoz, hogy az adott országról teljes képet kapjunk, amely segíthet a jövőbeli válságok előrejelzéséhez.

\section{LEHETSÉGES KUTATÁSI IRÁNYOK ÉS A KUTATÁS KORLÁTAI}

Úgy gondoljuk, hogy egy nemrégiben készült elemzés egy komplex tanulmány kezdete lehet. A 2020-as pandémiás válság felhívta a figyelmet arra, hogy az alapvető életszínvonalon túl a jó kormányzás is fontos szerepet játszik az ország azon védekező képességében, hogy megvédje a közegészséget, csökkentse a gazdasági visszaeséseket és enyhítse a társadalmi-politikai zavarokat (RobecoSAM, 2020b).

Több lehetséges jövőbeli kutatási téma kapcsolódhat a jelen cikk témájához: egyfelöl a vizsgálatot a világ összes országára ki lehetne terjeszteni, valamint nemcsak két évet, hanem hosszabb periódust lehetne vizsgálni. Ezen túl más, haladó ökonometriai modellek alkalmazásával is továbbfejleszthetnénk a jelenlegi eredményeket, valamint az egyes válságokra, mint például a 2020-as pandémiás válságra külön-külön összehasonlító elemzést lehetne készíteni.

Ennek a kutatásnak több korlátja is van. Elöször is további robusztus ellenőrzésekre van szükség az eredmények megbízhatóságának további növelése érdekében. Ezen túlmenően az eredmények csak a 2016-ra és 2010-re, valamint a kiválasztott adatokra érvényesek, ezért nem lehet általános következtetést levonni ebből az elemzésből. 


\section{HIVATKOZÁSOK}

Capelle-Blancard, G. - Crifo, P. - Diaye, M. A. - Scholtens, B. - Oueghlissi, R. (2016): Environmental, Social and Governance (ESG) performance and sovereign bond spreads: an empirical analysis of OECD countries. Retrieved from SSRN 2874262 (29 October 2020).

Capelle-Blancard, G. - Crifo, P. - Diaye, M. A. - Oueghlissi, R. - Scholtens, B. (2019). Sovereign bond yield spreads and sustainability: An empirical analysis of OECD countries. Journal of Banking \& Finance, 98, 156-169.

Comble, M. - Jenks, M. - Leue, H. - Lutz, V. - Singh, H. - Schmidt, J. (2019): ISS ESG Country Report 2019. Retrieved from https://www.issgovernance.com/library/esg-country-report-2019/ (29 October 2020).

Connolly, M. (2007): Measuring the effect of corruption on sovereign bond ratings. Journal of Economic Policy Reform 10(4), 309-323.

Crifo, P. - Diaye, M. A. - Oueghlissi, R. (2017): The effect of countries' ESG ratings on their sovereign borrowing costs. The Quarterly Review of Economics and Finance 66, 13-20.

De Franco, C. - Geissler, C. - Margot, V. - Monnier, B. (2020): ESG investments: Filtering versus machine learning approaches. arXiv preprint arXiv:2002.07477.

De Lucia, C. - Pazienza, P. - Bartlett, M. (2020): Does Good ESG Lead to Better Financial Performances by Firms? Machine Learning and Logistic Regression Models of Public Enterprises in Europe. Sustainability 12(13), 5317.

EBNER, A. (2009): An empirical analysis on the determinants of CEE government bond spreads. Emerging Markets Review 10(2), 97-121.

EICHLER, S. (2014): The political determinants of sovereign bond yield spreads. Journal of International Money and Finance 46, 82-103.

Escrig-Olmedo, E. - Fernández-Izquierdo, M. Á. - Ferrero-Ferrero, I. - Rivera-Lirio, J. M. - MuÑoz-Torres, M. J. (2019): Rating the raters: Evaluating how ESG rating agencies integrate sustainability principles. Sustainability 11(3), 915.

Friede, G. -Busch, T. - Bassen, A. (2015): ESG and Financial Performance. Aggregated Evidence from more than 2,00o Empirical Studies. Journal of Sustainable Finance and Investment 5(4), 210-233.

Gibson, R. - Krueger, P. - Riand, N. - Schmidt, P. S. (2019): ESG Rating Disagreement and Stock Returns Retrieved from SSRN 3433728 (29 October 2020).

Gu, S. - Kelly, B. - Xiv, D. (2018): Empirical asset pricing via machine learning (No. w25398). National Bureau of Economic Research.

HÜвEL, B. (2020): Do Markets Value ESG Risks in Sovereign Credit Curves? Retrieved from SSRN 3501100 (29 October 2020).

IBM (2020): Multilayer Perceptron. Retrieved from https://www.ibm.com/support/knowledgecenter/ SSLVMB_23.0.o/spss/neural_network/idh_idd_mlp_variables.html (29 October 2020).

KerTi NoÉMI - KeresztúRI JUdit LiLla (2017): Az osztalékpolitika ágazati hatásának érvényesülése Magyarországon. Köz-Gazdaság 12(3), 75-91.

Margaretic, P. - Pouget, S. (2018): Sovereign bond spreads and extra-financial performance: An empirical analysis of emerging markets. International Review of Economics \& Finance 58 , 340-355.

RoBECOSAM (2020a): Country Sustainability Ranking, retrieved from: https://www.robeco.com/ uk/key-strengths/sustainable-investing/country-ranking/ (29 October 2020). 
RobecoSAM (2020b): Country ESG Ranking Update - July 2020. Retrieved from https://www. robecosam.com/media/a/5/6/a565154e6efcd25e1197da40b69c1238_202008-robecosam-countryesg-ranking-robecosam_tcm1011-25282.pdf (29 October 2020).

Tarmuji, I. - Maelah, R. - Tarmuji, N. H. (2016): The impact of environmental, social and governance practices (ESG) on economic performance: Evidence from ESG score. International Journal of Trade, Economics and Finance 7(3), 67-74.

WorLd BANK (2020 a): Sovereign ESG Data Framework. Retrieved from https://databank.worldbank. org $/$ reports.aspx? source $=3711 \&$ series $=$ EN.POP.DNST\& country=EAS,SAS,MEA,SSF,LCN,ECS NAC (10 April 2020).

WORLD BANK (2020b): Economy \& Growth. Retrieved from https://data.worldbank.org/topic/ economy-and-growth (10 May 2020).

WORLD BANK (2020c): World Bank Country and Lending Groups. Retrieved from https:// datahelpdesk.worldbank.org/knowledgebase/articles/906519-world-bank-country-andlending-groups (31 October 2020). 